\title{
Competition effects and economic scenarios in an agroforestry system with cereal crops and wood plantations: a case study in the Po Valley (Italy)
}

\author{
Laura Rosso, \\ Simone Cantamessa, \\ Pier Mario Chiarabaglio, \\ Domenico Coaloa
}

\begin{abstract}
This study aims to evaluate the economic feasibility of agroforestry management in temperate latitudes. The surveys carried out in 1971 by Prevosto on the yields of wheat and rice combined with poplars was revised with updated prices to assess whether an agroforestry system can positively influence farm incomes. Based on Prevosto's dataset, four scenarios were simulated with poplar clone I-214, assuming four different positions of the poplar row (along the field borders, towards the cardinal points) and the relative shadows. The results show that the agroforestry system is economically advantageous, especially for wheat, and is directly related to wood price. The achievable benefits could be more significant with political and financial support that promotes these practices, taking into account the fundamental ecosystem services they provide.
\end{abstract}

Keywords: Agroforestry, Poplar, Cereal Crop, Shading Effect, Tree Row Orientation, Economic Evaluation, Threshold Area Convenience questration in biomass and soil, pest and pathogen reduction, moderate yield, reduction of soil erosion and nutrient leaching (Palma et al. 2007, Brooker et al. 2015). Damianidis et al. (2020) report that agroforestry system reduces wild-fires risk, as the integration of trees on culture crops determines a lower biomass accumulation in the ground. Moreover, agroforestry systems based on poplar are used as windbreak (Wyatt et al. 2019), decreasing the wind damage and limiting the soil evapotranspiration. Agroforestry combined with livestock farming is a common practice in arid environments, since conventional crop cultivation would not guarantee revenue in these fragile ecosystems (Singh et al. 1998). In temperate European agriculture systems, the monocropping management (both for food and timber production) is strongly subsidized compared to agroforestry. European and Italian policies have essentially ignored the agroforestry system in the last 30 years, and supports from the

CREA Research Centre for Forestry and Wood, str. Frassineto 35, I-15033 Casale Monferrato, $\mathrm{AL}$ (Italy)

@ Simone Cantamessa (simone.cantamessa@crea.gov.it)

Received: Apr 09, 2021 - Accepted: Jul 13, 2021

Citation: Rosso L, Cantamessa S, Chiarabaglio PM, Coaloa D (2021). Competition effects and economic scenarios in an agroforestry system with cereal crops and wood plantations: a case study in the Po Valley (Italy). iForest 14: 421-425. - doi: 10.3832/ifor3842-014 [online 202109-15]

Communicated by: Gianfranco Minotta

Common Agricultural Policy (CAP) and Rural Development Plants (RDPs) were tailored without intercropping between trees and crops (Facciotto et al. 2014).

Consequently, farmers used marginal agricultural land for tree plantations resulting in poor tree growth and relatively low gain (Minotta \& Paris 2010). Moreover, farmers and landowners do not consider agroforestry as a profitable alternative to standard agricultural practices since they believe that crops compete with young trees for resources, probably due to a lack of information. Several studies show that agroforestry can lead to beneficial effects without decreasing gains from crop cultivation. Graves et al. (2009) combined the intercropping walnut with fodder crops, and they reported that this could be one of the most profitable management systems in western Europe. Such silvoarable systems also present higher transpiration and generate microclimatic conditions with lower soil evaporation when compared with their equivalent monocropping cultivation (Pinto et al. 2019). Beneficial effects of silvoarable management are related to tree parameters, such as tree basal area, canopy, and tree density. It becomes crucial for agroforestry a better planning based on multi-species cropping system modeling (Bedoussac et al. 2015). Diversification of agroecosystems can cope with price and crop yield variability, thus increasing farmer's income stability and decreasing economic risk (Ramirez et al. 2001).

Our work aims to revisit the dataset collected by Prevosto (1971) to evaluate the actual feasibility of poplar in agroforestry combined with cash crops (wheat and rice) 


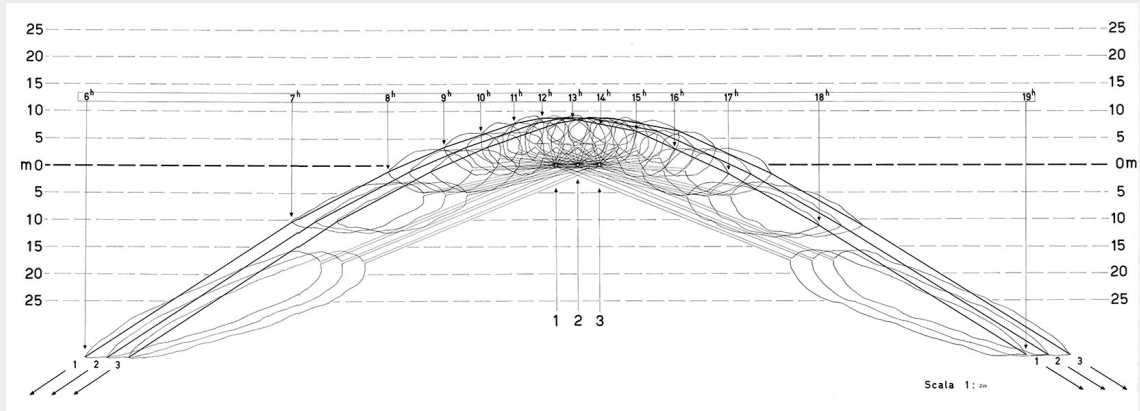

Fig. 1 - Shadow lengths of $25 \mathrm{~m}$ high poplar row, oriented West to East, on 15 June, at $45^{\circ}$ North latitude. The horizontal point labeled 1, 2, 3 are the three poplars that generate the shadows under/upper the poplar row at different hours of the day.

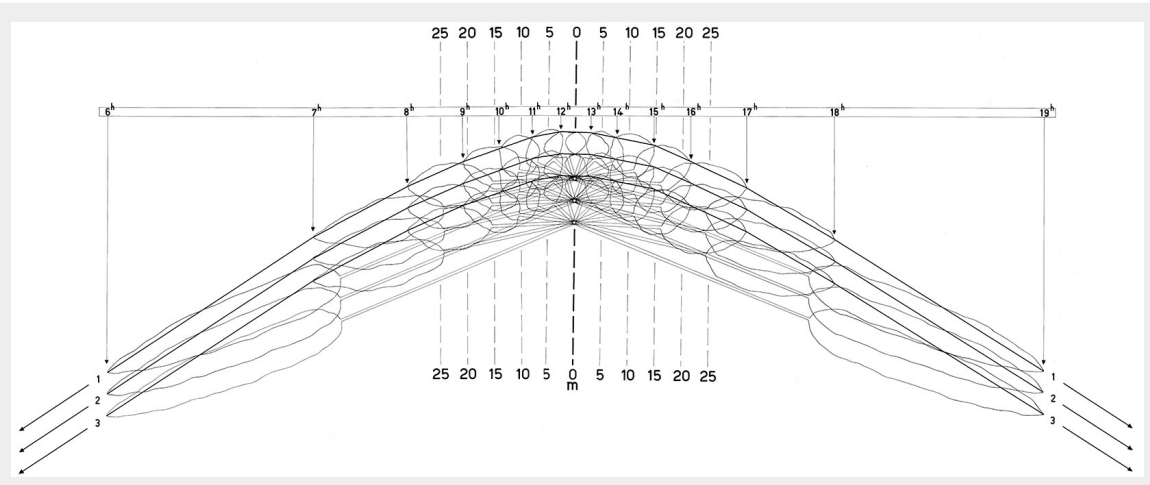

Fig. 2 - Shadow lengths of $25 \mathrm{~m}$ high poplar row, oriented North to South, on 15 June, at $45^{\circ}$ North latitude. The vertical points across the line labeled $0 \mathrm{~m}$ are the three poplars that generate the shadows right/left to the poplar row at different hours of the day.

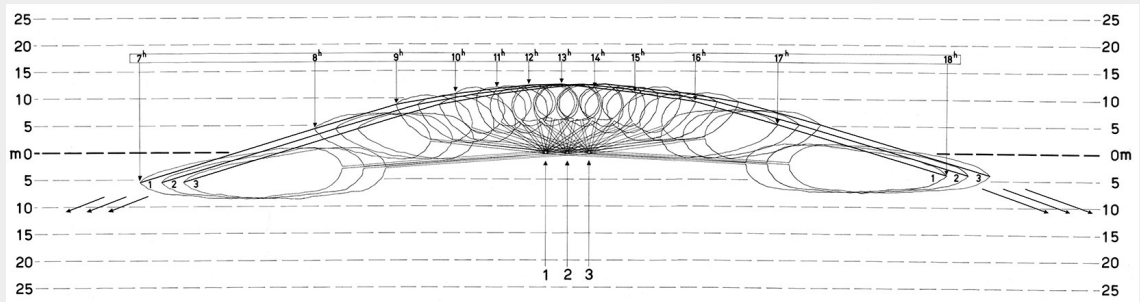

Fig. 3 - Shadow lengths of $25 \mathrm{~m}$ high poplar row, oriented West to East, on 15 August, at $45^{\circ}$ North latitude. The horizontal point labeled 1, 2, 3 are the three poplars that generate the shadows under/upper the poplar row at different hours of the day.

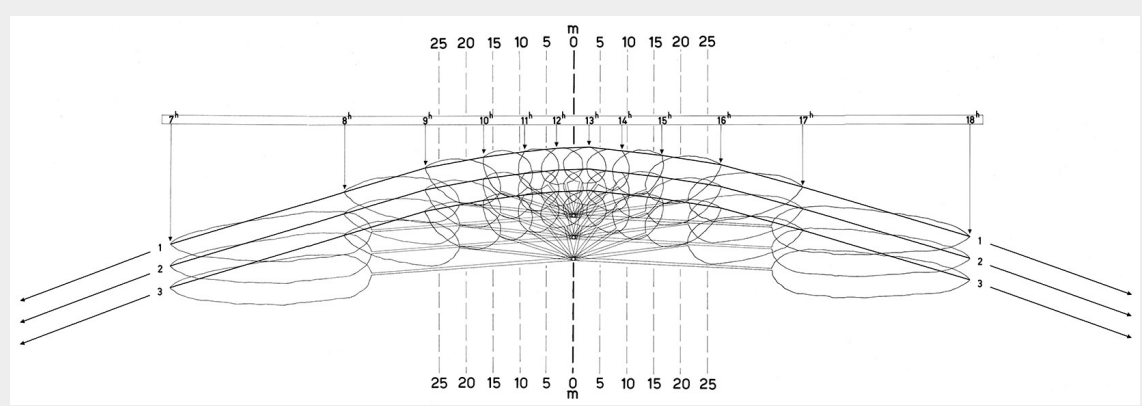

Fig. 4 - Shadow lengths of $25 \mathrm{~m}$ high poplar row, oriented North to South, on 15 August, at $45^{\circ}$ North latitude. The vertical points across the line labeled $0 \mathrm{~m}$ are the three poplars that generate the shadows right/left to the poplar row at different hours of the day.
Tab. 1 - Average reduction of the crop production in the first $25 \mathrm{~m}$ from the tree row by exposure (from Prevosto 1971).

\begin{tabular}{lcccc}
\hline \multirow{2}{*}{ Crop } & \multicolumn{4}{c}{ Average reduction (\%) } \\
\cline { 2 - 5 } & North & South & East & West \\
\hline Wheat & 21.4 & 8.7 & 17.0 & 18.5 \\
\hline Rice & 25.6 & 5.7 & 15.9 & 20.9 \\
\hline
\end{tabular}

in the Po Valley (Northern Italy). For many years farmers adopted the tree farming of poplar in field borders for different reasons, like fuel source, windbreaks, and private property fencing. Updated estimates of the advantages of this management system could be helpful for farmers.

\section{Material and methods}

\section{Former studies}

Prevosto (1971) carried out his surveys in ten farms located in the western-central part of the Po valley (Italy), in Spring-Summer months at the latitude $45^{\circ} \mathrm{N}$. The poplar trees (Populus $\times$ euramericana Dode Guinier "I-214") were planted in rows as field borders, spaced at a distance of $5 \mathrm{~m}$. Surveys were carried out for 10 years, and the results showed that up to the fourth year of plantation poplar rows did not influence the yield with any orientation. From the fifth year a decrease of production was noticed within $25 \mathrm{~m}$ from the poplar row. The highest reduction of yields was noticed on fields North of the poplars, and the lowest one southward. Intermediate decrease was found on fields East and West of the row (Tab. 1). Prevosto observed a direct effect of poplar roots and shadow from North, while only of roots for South (Fig. 1, Fig. 2, Fig. 3, Fig. 4). In a previous work on the same fields, Castellani \& Prevosto (1961) showed that improved fertilization reduced the decrease in crop yield of the South field, so the decrease was correlated to the poplar roots presence. The average reduction of yields in six years was higher for rice (loss of $25 \%$ in the yield of North exposed fields and $8 \%$ of South fields) than for wheat (loss of $21 \%$ in fields at North exposition and $7 \%$ in those at South - Tab. 1)

\section{Economic evaluation}

We simulated different economic scenarios of rice and wheat gains combined with two standing poplar wood prices for the veneer using data by Prevosto (1971) with updated cultivation techniques, yields, and market values. The management costs of the two cereal crops and those related to the poplar plantations during ten-year rotation were considered. The poplar plantation model is in single row with a $5 \mathrm{~m}$ spacing between trees in a field of $100 \times 100 \mathrm{~m}$ (1 hectare). For each cash crop, we assumed four different positions of the poplar row orientation for each cardinal 
point and the relative shadows, according to original dataset (Prevosto 1971) recorded in June and August. Tab. 2 reports all the agronomic management practices used for the economic calculation (Finassi 2017, Paris et al. 2019). Costs and earnings were estimated for a ten-year poplar cultivation cycle according to current prices (Tab. 3) and yield losses up to 25 meters away from the poplar row, as assessed by Prevosto (1971). Moreover, we also considered earnings from the sale of loose straw of wheat. For long-term investment, it is helpful to assess the Equivalent Annual Value (EAV - Merlo 1992, Pra \& Pettenella 2019, Pra et al. 2019). First, it is necessary to calculate the Net Present Value (NPV), according to eqn. 1. NPV (in $€$ ha $^{-1}$ ) is the difference between revenues and costs during the complete production cycle, discounted to year zero (Blanc et al. 2019 eqn. 1):

$$
N P V=\sum_{t=n}^{0} \frac{R_{t}-C_{t}}{(1+i)^{t}}
$$

where $R_{t}$ is the revenue from the agrosystem in the $t$-th year $\left(\epsilon \mathrm{ha}^{-1}\right), \mathrm{C}_{\mathrm{t}}$ are the costs in the $t$-th year $\left(\epsilon \mathrm{ha}^{-1}\right), i$ is the discount rate in the time horizon ( $n$ year). Then the EAV, i.e., the infinitive net present value converted to an annual payment (in $€ \mathrm{ha}^{-1} \mathrm{yr}^{-1}$ ), was calculated (Blanc et al. 2019). We chose a discount rate of 3.0\% for ten years, according to Pra et al. (2019).

$$
E A V=N P F \frac{i(i+1)^{n}}{(1+i)^{n}-1}
$$

No other specific risks such as disease, drought, phytosanitary problems, windblown, etc. have been considered in this study.

Two different scenarios were simulated with the current market values of the poplar stands of 50 (scenario 1) and $80 € \mathrm{t}^{-1}$ (scenario 2), according to Pra \& Pettenella (2019). The "Goal Seek" function in Microsoft Excel ${ }^{\circledR}$ was used to calculate the threshold area convenience, that is the minimum area above which economic convenience becomes positive.

\section{Results and discussion}

Two different scenarios were assessed using Prevosto (1971) surveys with updated agronomic costs and adding the value of poplar wood after ten years. The economic analysis showed that the profitability of an agroforestry system (poplar with rice or wheat) is related to poplar row orientation and poplar's market price. The competition for light between trees and crops is the factor that most discourages farmers from undertaking agroforestry, especially for Northern latitude farmers. It is a common belief that the lower elevation of the sun in the sky at high latitude (above $45^{\circ}$ ) leads to competition for light between the crops and trees due to a lower total annual radiation (Dupraz et al. 2018). Crop yield under shade depends on multiple factors, not only from the average global radiation dur-
Tab. 2 - Costs by phase and cultural operation ( $\left.€ \mathrm{ha}^{-1} \mathrm{yr}^{-1}\right)$ considered in the applied models for Wheat, Rice and Poplar row. $(*)$ : calculated for the first 4 years; $(* *)$ : harvesting costs were not included since trees were sold as standing trees, according to Pra et al. (2019).

\begin{tabular}{llccc}
\hline \multirow{2}{*}{ Phase } & Operation & \multicolumn{3}{c}{ Costs $\left(€\right.$ ha $\left.^{-1} \mathbf{y r}^{-1}\right)$} \\
\cline { 3 - 5 } & Soil preparation & Wheat & Rice & $\begin{array}{c}\text { Poplar } \\
(20 \text { trees })\end{array}$ \\
\hline \multirow{3}{*}{ Planting } & Fertilization & 200 & 190 & - \\
& Seeding/planting & 150 & 200 & - \\
\hline \multirow{2}{*}{ Cultivation } & Irrigation & 150 & 250 & 140 \\
\cline { 2 - 5 } & Pesticide/weed control/pruning & - & 200 & - \\
\hline Harvesting & Harvest & 150 & 490 & $30^{*}$ \\
\hline
\end{tabular}

Tab. 3 - Production in tons ( $t$ ) per hectare and price (in Euro per ton) for wheat, rice

\begin{tabular}{|c|c|c|c|c|}
\hline \multirow{2}{*}{ Parameters } & \multicolumn{2}{|c|}{ Wheat } & \multirow{2}{*}{ Rice } & \multirow{2}{*}{$\begin{array}{c}\text { Poplar } \\
\text { (20 trees) }\end{array}$} \\
\hline & grains & straw & & \\
\hline Production $(\mathrm{t})$ & 6.12 & 5 & 6.45 & 14 \\
\hline Price $\left(€ \mathrm{t}^{-1}\right)$ - Scenario 1 & 210 & 20 & 350 & 50 \\
\hline Price $\left(€ \mathrm{t}^{-1}\right)$ - Scenario 2 & 210 & 20 & 350 & 80 \\
\hline
\end{tabular}
and poplar in row.

Tab. 4 - Comparison of crop and agroforestry incomes (EAV) in the systems evaluated in a field of 1 hectare according to the four row orientations. (Scenario 1): poplar

\begin{tabular}{|c|c|c|c|c|c|c|c|}
\hline \multirow[b]{2}{*}{ Exposure } & \multirow[b]{2}{*}{ Area } & \multicolumn{3}{|l|}{ Wheat } & \multicolumn{3}{|l|}{ Rice } \\
\hline & & Alone & $\begin{array}{c}\text { +Poplar } \\
\text { (scenario 1) }\end{array}$ & $\begin{array}{c}\text { +Poplar } \\
\text { (scenario 2) }\end{array}$ & Alone & $\begin{array}{c}\text { +Poplar } \\
\text { (scenario 1) }\end{array}$ & $\begin{array}{c}\text { +Poplar } \\
\text { (scenario 2) }\end{array}$ \\
\hline North & $1 \mathrm{ha}$ & \multirow{4}{*}{587.20} & 576.86 & 613.49 & \multirow{4}{*}{660.78} & 623.90 & 660.54 \\
\hline South & 1 ha & & 601.67 & 638.31 & & 687.27 & 723.91 \\
\hline East & 1 ha & & 585.45 & 622.09 & & 654.79 & 691.43 \\
\hline West & 1 ha & & 582.52 & 619.16 & & 638.87 & 675.51 \\
\hline
\end{tabular}
wood values of $50 € \mathrm{t}^{-1}$; (Scenario 2): poplar wood values of $80 € \mathrm{t}^{-1}$.

ing the growing season. The photosynthet- price of poplar wood (Tab. 4). We estiic capacities are related to instantaneous mated the highest yield reduction in the microenvironmental conditions, as the scenario of wheat and poplar cultivation path of the sun, tree planting density, silvi- with poplar value of $50 € \mathrm{t}^{-1}$ (scenario 1) and cultural practices and tree phenological North exposure of the field, where the loss stage (Artru et al. 2017). Our simulations reaches $10.34 € \mathrm{yr}^{-1}$; while in the southward showed that wheat or rice in combination one there was an increase in the EAV equal with poplar could be a good choice for to $14.47 € \mathrm{yr}^{-1}$. In all cases of the $80 € \mathrm{t}^{-1} \mathrm{sce}$ farmers depending on row orientation and nario (current market price updated to

Tab. 5 - Threshold area convenience (in ha) above which economic convenience becomes positive for the agricultural systems studied. (Scenario 1): poplar wood values of $50 € \mathrm{t}^{-1}$; (Scenario 2): poplar wood values of $80 € \mathrm{t}^{-1}$.

\begin{tabular}{clcc}
\hline Crop & Exposure & $\begin{array}{c}\text { Scenario 1 } \\
\text { (ha) }\end{array}$ & $\begin{array}{c}\text { Scenario 2 } \\
\text { (ha) }\end{array}$ \\
\hline \multirow{3}{*}{ Wheat } & North & 1.02 & 0.96 \\
& South & 0.98 & 0.92 \\
& East & 1 & 0.94 \\
& West & 1.01 & 0.95 \\
& North & 1.06 & 1 \\
\hline \multirow{3}{*}{ Rice } & South & 0.96 & 0.91 \\
& East & 1.01 & 0.96 \\
& West & 1.03 & 0.98 \\
\hline
\end{tabular}


2020), the agroforestry system provides an economic advantage that ranges from $51.11 € \mathrm{yr}^{-1}$ for the Southern exposure to $26.29 € \mathrm{yr}^{-1}$ for the Northern exposure. Concerning rice, with a wood value of $50 €$ ton (scenario 1), the loss ranges from $36.88 €$ $\mathrm{yr}^{-1}$ in the North facing field to $5.99 € \mathrm{yr}^{-1}$ for the eastward one; the South row leads to an increase of $26.49 € \mathrm{yr}^{-1}$. In the scenario 2 (poplar wood value of $80 €$ per ton) the estimated loss is only $0.24 € \mathrm{yr}^{-1}$ in the fields with Northern exposure, while earnings ranges from $14.73 € \mathrm{yr}^{-1}$ in West exposures to $63.13 € \mathrm{yr}^{-1}$ in Southern exposures. The threshold area convenience is reported in Tab. 5. For wheat, in the first scenario the southward field reaches the threshold convenience with an area below 1 ha (0.98). In the second scenario, all the row orientation reaches the threshold area convenience below 1 ha. For rice cultivation, in the first scenario only the South field reached the threshold area convenience below 1 ha; the other orientations need an area up to 1 ha for the same earning of the crop alone. In the second scenario, all the field reach the threshold area convenience below 1 ha.

The differences between the gains from the two cash crops are mainly due to the life cycle of the crops: rice is spring cultivation and carries out a large part of its photosynthetic activities starting from the end of April/beginning of May, a period in which the poplars foliage is already developed (Moldenhauer et al. 2001). Moreover, water temperature in rice paddies is one of the most critical factors affecting the growth and yield of rice (Moldenhauer et al. 2001); in summer, the release of poplar's cottonseed could decrease the water temperature of rice paddies due to a more reflection of the incident light (Decoteau et al. 1989). On the contrary, wheat is an autumn-winter crop and consolidates its development before the full development of the poplar foliage, with a lower impact on yield. Finally, this work shows that profit does not depend on supporting funds. The absence of subsidies and the markets' insecurity are some aspects that strongly discourage investing in agroforestry, in addition to the long crop cycle. To encourage these agroforestry practices, national and international support to farmers is mandatory (Blanc et al. 2019).

\section{Conclusion}

The new social, economic, and biological challenges and the progressive decrease of natural resources combined with climate change require new approaches to knowledge and innovation, and above all to political choices. The concept of "bioeconomy" or "bio-based society" has become an important component of national, EU and global policies, in which a transition from fossil sources to a more efficient bio-based economy based on renewable sources takes place through sustainable processes which also provide ecosystem service. In the above context, agroforestry based on poplar could be a good choice for farmers. Future investigations will be focused on the effects of shade West and East exposition, and on cultivation in rows of a group of poplars clones named "MSA" (in Italian "Maggior Sostenibilità Ambientale" = greater environmental sustainability), which have been selected for their lower cultivation needs in terms of treatments and management (Corona et al. 2018).

\section{References}

Artru S, Garré S, Dupraz C, Hiel MP, Blitz-Frayret C, Lassois L (2017). Impact of spatio-temporal shade dynamics on wheat growth and yield, perspectives for temperate agroforestry. European Journal of Agronomy 82: 60-70. - doi: 10.1016/j.eja.2016.10.004

Bedoussac L, Journet EP, Hauggaard-Nielsen H, Naudin C, Corre-Hellou G, Jensen ES, Pieur L, Justes $E$ (2015). Ecological principles underlying the increase of productivity achieved by cerealgrain legume intercrops in organic farming. A review. Agronomy For Sustainable Development 35 (3): 911-935. - doi: 10.1007/s13593-0140277-7

Blanc S, Accastello C, Bianchi E, Lingua F, Vacchiano $G$, Mosso A, Brun F (2019). An integrated approach to assess carbon credit from improved forest management. Journal of Sustainable Forestry 38 (1): 31-45. - doi: 10.1080/105498 11.2018.1494002

Brooker RW, Bennett AE, Cong WF, Daniell TJ, George TS, Hallett PD, Hawes C, lannetta PPM, Jones HG, Karley AJ, Li L, McKenzie BM, Pakeman RJ, Paterson E, Schöb C, Shen J, Squire G, Watson CA, Zhang C, Zhang F, Zhang J, White PJ (2015). Improving intercropping: a synthesis of research in agronomy, plant physiology and ecology. New Phytologist 206 (1): 107-117. - doi: 10.1111/nph.13132

Castellani E, Prevosto M (1961). Experimental contribution on the study concerning the relation between poplars grown on fields' borders and some agricultural crops. In: Proceedings of the $13^{\text {th }}$ IUFRO Meeting. Vienna (Austria), Sept 1961. International Union of Forest Research Organizations - IUFRO, Vienna, Austria, pp. 1016.

Corona P, Bergante S, Castro G, Chiarabaglio PM, Coaloa D, Facciotto G, Gennaro M, Giorcelli A, Rosso L, Vietto L, Nervo G (2018). Linee di indirizzo per una pioppicoltura sostenibile [Guidelines for sustainable poplar cultivation]. Rete Rurale Nazionale, Consiglio per la ricerca in agricoltura e l'analisi dell'economia agraria, Roma. [in Italian]

Damianidis C, Santiago-Freijanes JJ, Den Herder M, Burgess P, Mosquera-Losada MR, Graves A, Papadopoulos A, Pisanelli A, Camilli F, Rois-Díaz M, Kay S, Palma JHN, Pantera A (2020). Agroforestry as a sustainable land use option to reduce wildfires risk in European Mediterranean areas. Agroforestry Systems 95 (5): 919-929. doi: 10.1007/s10457-020-00482-w

Decoteau DR, Kasperbauer MJ, Hunt PG (1989). Mulch surface color affects yield of fresh-market tomatoes. Journal of the American Society for Horticultural Science 114 (2): 216-219. [online] URL: http://pubag.nal.usda.gov/catalog/17
874

Dupraz C, Blitz-Frayret C, Lecomte I, Molto Q, Reyes F, Gosme M (2018). Influence of latitude on the light availability for intercrops in an agroforestry alley-cropping system. Agroforestry Systems 92: 1019-1033. - doi: 10.1007/s104 57-018-0214-x

Facciotto G, Minotta G, Paris P, Pelleri F (2014). Tree farming, agroforestry and the new green revolution. A necessary alliance. In: Proceedings of the $2^{\text {nd }}$ International Congress of Silviculture "Designing the future of the forestry sector". Florence (Italy) 26-29 Nov 2014. Accademia Italiana di Scienze Forestali, Firenze, Italy, vol. 2, pp. 658-669.

Finassi A (2017). Il bilancio economico dell'azienda risicola [The economic balance of the rice farm]. Associazione Laureati in Scienze Agrarie e Forestali Vercelli e Biella, Camera di Commercio di Biella e Vercelli, Italy, pp. 37. [in Italian] [online] URL: http://www.risoitaliano. eu/customcontents/bil17.pdf

Graves AR, Burgess PJ, Liagre F, Pisanelli A, Paris P, Moreno G, Bellido M, Mayus M, Postma M, Schindler B, Mantzanas K, Papanastasis VP, Dupraz C (2009). Farmer perceptions of silvoarable systems in seven European countries. In: "Agroforestry in Europe" (Rigueiro-Rodróguez A, McAdam J, Mosquera-Losada MR eds). Advances in Agroforestry, vol. 6, Springer, Dordrecht, Netherlands, pp. 67-86. - doi: 10.1007/ 978-1-4020-8272-6_4

Merlo M (1992). Elementi di economia ed estimo forestale [Elements of forestry economics and estimation]. Pàtron ed., Bologna, Italy, pp. 546. Minotta G, Paris P (2010). Workshop del GdL SISEF “Arboricoltura da legno" sulle piantagioni di latifoglie a legno pregiato e presentazione di ARBORA, il database on-line degli impianti da legno di latifoglie [Workshop of the SISEF Working Group "Forest plantations" on the current situation of noble hardwood plantations in Italy and presentation of ARBORA the on-line database]. Forest@ 7: 247-248. [in Italian with English summary] - doi: 10.3832/ eforo645-0007

Moldenhauer K, Counce P, Hardke J (2001). Rice growth and development. In: "Rice Production Handbook" (Hardke T ed). University of Arkansas Cooperative Extension Service, Little Rock, AR, USA, pp. 9-20. [online] URL: http://www. uaex.edu/publications/pdf/mp192/chapter-2-wo rd.pdf

Palma J, Graves AR, Burgess PJ, Van Der Werf W, Herzog F (2007). Integrating environmental and economic performance to assess modern silvoarable agroforestry in Europe. Ecological Economics 63 (4): 759-767. - doi: 10.1016/j.ecol econ.2007.01.011

Paris $P$, Leonardi L, Cherubini $M$, Chiocchini $F$, Lauteri M, Pisanelli A, Dalla Valle C, Mezzalira G, Sangiovanni M, Facciotto G, Nervo G, Coaloa D (2019). Hybrid poplars for timber with arable crops in Italy: innovating the tradition facing Global Changes. In: Proceedings of the " $4^{\text {th }}$ World Congress on Agroforestry". Montpellier (France) 20-22 May 2019. CIRAD, Paris, France, pp. 314.

Pinto VM, Van Dam JC, De Jong Van Lier Q, Reichardt K (2019). Intercropping Simulation Using the SWAP Model: Development of a $2 \times 1 \mathrm{D}$ 
Algorithm. Agriculture 9 (6): 126. - doi: 10.3390/ agricultureg060126

Prevosto M (1971). Alcuni aspetti della coltura di ripa del pioppo [Some aspects of poplar culture on field-borders]. Ente nazionale Cellulosa e Carta - ENCC, Roma, Italy, vol. 6, pp. 23-44.

Pra A, Brotto L, Mori P, Lattes EB, Masiero M, Andrighetto N, Pettenella D (2019). Profitability of timber plantations on agricultural land in the Po valley (northern Italy): a comparison between walnut, hybrid poplar and polycyclic plantations in the light of the European Union Rural Development Policy orientation. European Journal of Forest Research 138 (3): 473 494. - doi: 10.1007/s10342-019-01184-4

Pra A, Pettenella D (2019). Investment returns from hybrid poplar plantations in northern Italy between 2001 and 2016: are we losing a bio- based segment of the primary economy? Italian Review of Agricultural Economics 74 (1): 49-71. [online] URL: http://oajournals.fupress.net/inde x.php/rea/article/download/9953/9950

Ramirez OA, Somarriba E, Ludewigs T, Ferreira P (2001). Financial returns, stability and risk of cacao-plantain-timber agroforestry systems in Central America. Agroforestry Systems 51 (2): 141-154. - doi: 10.1023/A:1010655304724

Rigueiro-Rodríguez A, Fernández-Núñez E, González-Hernández P, McAdam JH, MosqueraLosada MR (2009). Agroforestry systems in Europe: productive, ecological and social perspectives. In: "Agroforestry in Europe" (RigueiroRodróguez A, McAdam J, Mosquera-Losada MR eds). Advances in Agroforestry, vol. 6, Springer, Dordrecht, Netherlands, pp. 43-65. doi: 10.1007/978-1-4020-8272-6 3
Singh M, Arrawatia ML, Tewari VP (1998). Agroforestry for sustainable development in arid zones of Rajasthan. International Tree Crops Journal 9 (3): 203-212. - doi: 10.1080/0143569 8.1998.9752976

Smith J, Pearce BD, Wolfe MS (2012). A European perspective for developing modern multifunctional agroforestry systems for sustainable intensification. Renewable Agriculture and Food Systems 27 (4): 323-332. - doi: 10.1017/S1742170 511000597

Wyatt G, Sames A, Zamora DS (2019). Agroforestry practices: windbreaks. In: "Agroforestry for Sustainable Agriculture" (Mosquera-Losada MR, Prabhu R eds). Burleigh Dodds Science Publishing, London, UK, pp. 21-37. - doi: 10.1910 3/AS.2018.0041.02 